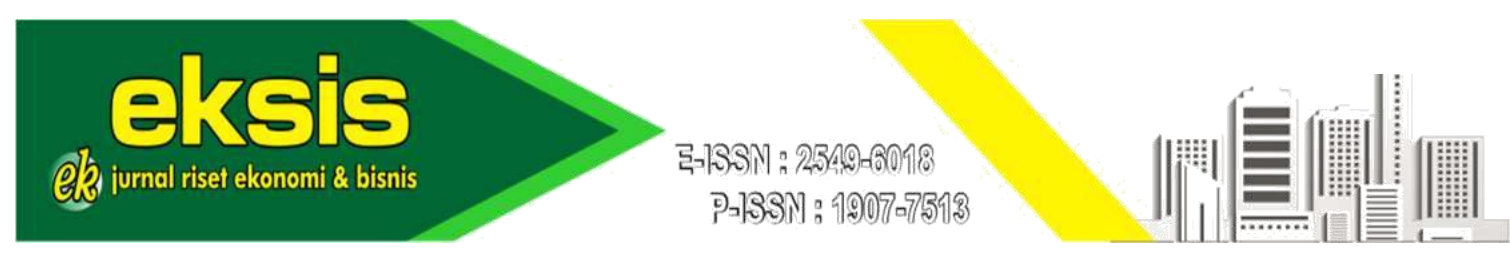

\title{
Changes In Community Consumption Patterns Due To The Covid-19 Pandemic
}

\author{
Andriani \\ Institute Agama Islam Negeri (IAIN) Kediri \\ Correspondence: andriani@iainkediri.ac.id
}

Submitted: 5 February 2021, Revised: 21 April 2021, Published: 23 June, 2021

\begin{abstract}
The Covid-19 pandemic has changed people's consumption patterns. On the one hand, the community is required to sort out and choose needs that are on a priority scale. On the other hand, people want the needs of life to be fulfilled to the fullest. This research objects to analyze changes in community consumption patterns due to covid-19. This study uses a qualitative approach with a literature study method. The data used in this study are secondary, in the form of research from institutional data AND scientific journals both print and online which selected based on four aspects, namely: 1) Provenance; 2) Objectivity; 3) Persuasiveness; 4) Values. The results of the study SHOW THAT, in general, the poor are only able to meet their primary needs. The middle class almost fulfills all their needs, both primary, secondary, and tertiary needs. The upper class can meet all their needs, both primary and tertiary. The Covid-19 pandemic also changing society's consumption patterns from consumption habits to tending to realistic. The quantity of consumption is relatively constant but the quality is decreasing. The increase in consumption allocation is more on prioritizing food quality and food diversity. Additionally, a new trend for shopping is appearing online through certain marketplace, so there is a new trend in the form of utilization of digital wallets or other non-cash transactions.
\end{abstract}

Keywords: Consumption patterns, Pandemic, Covid-19,

\section{A. INTRODUCTION}

The Covid-19 pandemic has had a positive impact on people's consumption patterns. On the one hand, the community is required to sort out and choose needs that are on a priority scale. On the other hand, people want the needs of life to be fulfilled to the fullest. People's consumption patterns are divided into two parts, namely those affected and those not affected by the Covid-19 pandemic. Those affected by Covid-19 will adjust to the general income situation.

John Maynard Keynes argued that the income earned by individuals influences the great level of need in the household. (Keynes, 1938, p. 90) Franco Modigliani explained that the amount of use of household needs does not depend only on the amount of income, but also on the amount of wealth owned, where this wealth comes from savings, investments, income allowance, inheritance, and so forth. (Suparmoko, 1991)

Community consumption patterns are formed from smaller components, namely individuals and families. BPS categorizes individuals based on age into 2 groups: First, unproductive age (Age 0-14 year old, Age 65+); Second, the productive age (Age 1565 ). (Indonesia Statistics Bureau). Furthermore, an ordinary household is an individual or group of people who inhabit part or all of a physical building or census, and usually, live together and take care of their daily needs together as one. Meanwhile, people who live in shared residences such as dormitories managed by a foundation or institution; social institutions such as detention centers or the like; social institutions such as orphanages and nursing homes; and Homestays dal am the places where the number of large/ approximately 10 people (Indonesia Statistics Bureau) 
On January 30, 2020, the World Bank released a report on Indonesia, in which the World Bank divided Indonesians into five groups based on monthly expenditure as shown in the table below:

Table 1: Classification of the Economic Level of Indonesian Society according to the World Bank

\begin{tabular}{llc}
\hline No. & \multicolumn{1}{c}{ Category } & Spending Range (per month) \\
\hline 1 & Poor Group & $<$ Rp. 354,000 \\
\hline 2 & Susceptible Group & Rp. 354,000 - Rp. 532,000 \\
\hline 3 & Towards Intermediate Group & Rp. 532,000 - IDR 1,200.00 0 \\
\hline 4 & Medium Safe Group & IDR 1,200,000 - IDR 6,000,000 \\
\hline 5 & High class Group & $>$ IDR 6,000,000 \\
\hline
\end{tabular}

Source: Aspiring Indonesia - Expanding the Middle Class

World Bank, 30 January 2020. (The World Bank, 2020)

In addition to the World Bank which classifies Indonesians into five groups, Indonesia Statistic Bureau categorizes people into three economic groups, namely: lower, middle, and upper economic groups. Each has different criteria in meeting needs including primary, secondary, and tertiary needs. Most of the people affected by COVID-19 come from low/weak economies.

The criteria are weak people will the economy can be identified by characteristics such as the following: have occupancy with an area of less than 8 $\mathrm{m}^{2}$ every member of the family with the base housing with soil floor with a wall section made of bamboo shades or the like; sanitation facilities are owned jointly, not per dwelling; do not use electricity as a residential lighting source; facilities for water supply in the form of wells, rivers or unprotected springs; wood and charcoal are resources that are used as daily fuel; the intensity of consumption of meat or similar is very rare, only once a week; the need to purchase clothes only once a year; intensity to eat only once until twice a day, inability in paying basic health fee; have an income of IDR 600,000 per month or equivalent to a farmer with $500 \mathrm{~m}^{2}$; the head of the household has an education level commensurate with elementary school or not; does not have any valuables that could be used as a savings / liquid goods for sale minimally valued at IDR. 500,000.

The character of people with an economy moving towards the middle class is also a point to note because in this group the sensitivity to economic shocks will be felt when there are certain factors such as illness, accidents, or natural disasters. At the level of the economy towards the middle class has the highest dominance of education equivalent to high school, where the need for educational formation at this level informal jobs has a fairly high salary. The available public services include education and health facilities provided by the government.

At the level of the middle-class economy, the stability of the economy is more resistant to shocks from problems that occur such as illness, accidents, and natural disasters. Even in the middle economic level the opportunity to move up to the upper class. The level of education in this group has received a lot of higher education. The health facilities used by the majority of this level are privately owned where the quality and services are better than those of the government. This will have a positive impact if the majority of the population in a country has a higher proportion of the middle group. It can accelerate economic growth with the level of public consumption. In addition, they also contribute to state income in the form of taxes. This 
group has a high level of productivity such as working as office employees or as reliable business people. Also, they are vocal about a good democratic process.

Indonesia's economic growth over the last five decades has been able to grow, with an average growth of $5.6 \%$. Where in 1993, approximately $80 \%$ of Indonesia's population was in the poor category. Now Indonesia is a middle-income country in 2014 (World Bank, 2020). An increase in the percentage of the population with an economy moving towards the middle class can increase Indonesia to become a country with a high-income economy, where Indonesia's welfare will also follow this positive trend. This should be supported by regulations and policies that support services for the public to be better, the existence of solid social protection and acceptance of the obligations of citizens as state income from taxes. Based on Indonesia Statistics Bureau in March 2020, the poor in Indonesia have a level percentage of $9.78 \%$, increased by $0.56 \%$ basis points on the second half of 2019 ( September ), and increased by $0.37 \%$ basis point in March of the same year. The number of poor people in Indonesia in March 2020 increased by 1.63 million to 26.42 compared to the amount in September 2019, an increase of 1.28 million when compared with the number of poor people in March 2019.

If it is grouped by region, poor people in areas of the city in March 2020 has the percentage rate of $7.38 \%$ (equivalent to 11.16 million), which is an increase of $0.82 \%$ (equivalent to 1.3 million people ) which at the beginning of $6.56 \%$ (equivalent to 9.86 million) September 2019. Meanwhile, based on the percentage of the rural areas in March 2020 recorded a percentage of $12.82 \%$ (equivalent to 15.26 million) where the poor population increased by $0.22 \%$ ( equivalent to 333.9 thousand people) which initially in September 2019 had a percentage of $12.60 \%$ (equivalent to 14.93 million people)

Based on the calculation of the poverty line in Indonesia, in March 2020 obtained IDR 454,652 with the composition of expenditure for food of IDR 335,793 or equivalent to $73.86 \%$ and non-food expenditures of IDR 118,859 or equivalent to $26.14 \%$ with an average family member with a poor category of the economic level of 4.66 people. Thus, when calculated per family by the average number of family members that result in spending during the month amounted to IDR 2,118,678

The Covid-19 pandemic resulted in a lot of influence on society, both issues in the employment level of income and consumption levels. Another study explained that Covid-19 had an impact in shifting profession were initially engaged sector agriculture into the non-agricultural sector. This is done by farming families to continue to have activities that generate family income. (Kartika \& Novitriani, 2021). The decline in revenue will also affect the consumption level. Other studies mention a decrease in food demand and changes in people's food consumption patterns in terms of quantity, quality, and food purchasing patterns as a result of decreased income and purchasing power (Ariani et al., 2020)

The problem in this study are: 1) What is the pattern of consumption s Before the pandemic period COVID-19? 2) How are people's consumption patterns during the COVID-19 pandemic?

\section{B. LITERATURE REVIEW}

Activities to fulfill the need for food, goods, and services that are always ready to be used by households can be defined as consumption (McEachern, 2001, p. 490). In relation to the process of economic activity, consumption is the ultimate goal of 
economic activity where the product or service can be absorbed by the community (Gilarso, 1993, p. 89). Based on Indonesia Dictionary, consumption is defined as an activity carried out implicitly or explicitly in the satisfaction of the necessities of life by reducing the level of utility of an item (Winarno \& Ismaya, 2007, p. 115)

Nicholas Gregory Mankiw in his opinion states that consumption is a household expenditure in the form of goods or services. The results of goods from household expenditures can be classified into two types, namely: durable goods (vehicles, land, houses, etc.) and non-durable goods (food, clothing, daily necessities), while the service itself is an intangible thing that does not have a form that consists of services for education, health, and so on (Mankiw, 2006, p. 11)

According to John Maynard Keynes, the level of income is the main variable in the formation of the level of household consumption expenditure. The consumption formula is $\mathrm{C}=\mathrm{f}(\mathrm{Y})$. There are 3 main assumptions in this theory, namely: (Keynes, 1938; Nopirin, 2015, p. 80) first, there is a tendency to marginally maximize activities using a good or service if there is an addition of 0 and 1 ; second, there is a tendency to use goods or services on an average; third, the absence of interest rate intervention on consumption, making the amount of income received becomes one of the important things in consumption decisions (Mankiw, 2006, pp. 425-426)

In his opinion, Keynes explained macro economically from the consumption function itself where there was a relationship between national income and consumption outcomes when prices are fixed. Assuming that income is state income in a certain period, where in the consumption function, national income is the sum of fixed income and relative income compared to absolute national income. Keynes stated that the small and large consumption of society is determined by income. The size of the savings has no effect on the increase or decrease in the number of goods and services that will be consumed by the community.

Milton Friedman in his theory stated that people's income was based on two classifications, namely permanent income and transitory income. The definition of permanent income is income that people expect to survive in the future (Mankiw, 2006, p. 44). The definition of temporary income is income that cannot be predicted in advance. In his opinion, Friedman divided consumption expenditure into 2 parts, namely: planned consumption and accidental consumption. He argues that there is no relationship whatsoever between consumption and income, both planned consumption and accidental consumption. Consumption of temporary income tends to $=0$. Friedman argued that there was no relationship between income and consumption. It was fixed and variable income and consumption or temporary consumption with temporary income. There is a consumption trend based on temporary income $=0$, which means that if consumers receive positive temporary income, it does not affect consumption. If consumers have no income, they do not reduce consumption (Algifari, 1998, p. 72) Current income will temporarily decrease. It can be concluded that consumption according to Milton Friedman stated that permanent income will affect the size of the average consumption pattern of the community. The tendency of people in consumption can lead to the size of the average consumption pattern of the community. The tendency of people in consumption can lead to the type of food and or non-food depending on the amount of income received by the community (Mankiw, 2006, p. 444)

Franco Modigliani mentions in the theory of consumption based on the life cycle, where the consumption pattern of a person is strongly influenced by a person's socioeconomic status. In this theory there are 3 consumption patterns based on a 
person's age, where: 1) a person's income is low when he is young, influences the savings ratio that changes in line with increasing age, a person will have negative savings (dissaving); 2) when they reach a mature age where productivity is high, income tends to be high, they will save the wealth for savings and pay off loans when they are young; 3) when they reach an age that is no longer young or can be said to be old and less productive, they tend to use the savings collected during their productive period. If this savings has been exhausted, it will experience negative savings (Algifari, 1998, pp. 66-67)

Franco Modigliani also argues about the management of income and savings in a structured manner so that they can be used during fluctuating conditions (Mankiw, 2006, p. 439) The theory concludes that a person's consumption is influenced by wealth and or the amount of income earned. Age, tastes, and interest rates of consumers affect the value of one's consumption. James Dusenberry's opinion regarding relative income in consumption theory, states that consumption expenditure by society is based on the highest income (Dusenberg, 1967, pp. 43-45) The amount of consumption will increase as income increases. The amount of savings will be reduced when maintaining a high level of consumption. The tendency of people to reduce consumption when the income earned is small or reduced. Thus, the consumption portion will be lower when compared to when the income received is high and the consumption portion is also high. (Algifari, 1998) If income increases, it will increase spending for consumption, while the increase in savings is not too large (Reksoprayitno, 2000)

Dusenberry theory assumes that there are 2 conditions of consumption behavior, namely: First, the amount of a person's consumption depends on the highest income compared to the previous year (Ratchet Effect); Second, a person's consumption behavior is also influenced by consumption behavior in the environment/ Demonstration Effect (Algifari, 1998, p. 72; Dusenberg, 1967). Thus, the conclusion obtained is that there is a relationship between expenditure for consumption and the amount of income received so that income at a certain amount will be in line with the amount of consumption expenditure.

The consumption function is the amount of consumption that is decided by the community based on income (Subagyo). The consumption function is a curve that shows the nature of the relationship between household consumption and national income in the national economy of a country (Wardayadi) Consumption Keynes in his concept-based that in his hypothesis there is a stable empirical relationship between consumption and income. If the number of income increases, consumption will increase relatively, but in a smaller proportion compared to the increase in income. This is because the marginal consumption tendency will decrease if income increases.

Keynes's thinking about consumption explains that a person will not spend all their expenses with all the results of an increase in income. This is based on the fact that people who are richer or have more income will consume less and less. Where is the concept of bias between consumption and saving? This concept is used to determine the nature of the relationship that occurs between income that has a plan for its use in consumption with expenses to be purchased and income that is used unplanned with expenses to be purchased.

The consumption tendency explains the relationship where the tendency in meeting needs can be divided into two, namely: 1) marginal consumption (MPC) and 2) average consumption (APC). Where marginal consumption is the result of a comparison 
of the magnitude of the increase in the fulfillment of needs carried out with the planned income for its use

Salvatore expressed his opinion about consumer behavior, individuals will rationally maximize consumption with the aim of self-satisfaction following the income earned. (Dominick, 2007, p. 53) This is different from what Ni Made Suyastiri YP said, in which household food consumption aims to strengthen food security in terms of quality and quantity. consumption (YP, 2008). It can be concluded that the end of the activity of fulfilling the needs is the achievement of an optimal level of welfare in consumption, meaning that all needs are met both in terms of quality and quantity.

The classification of purchasing options is classified as follows: (a) Important consumption, where the lack of experience in decision making makes this expenditure very rare because it takes more effort to make decisions. (b) Routine consumption, where the activity to fulfill this need has become routine when the goods needed have been exhausted, it does not require more effort in decision making because it has become routine; (c) Emergency consumption, where the expenditure on the need for services or goods is unexpected and emergency.

Consumption patterns are activities to fulfill goods and services which are an individual or collective needs based on the type of classification of the level of need (Singarimbun, 1978). This pattern consists of the composition of the ingredients consumed by the average person daily, the type that is often used in a certain period by the community (Ministry of Indonesia Agriculture, 2016). Lie Goan Hong explained that consumption patterns were a variety of information that provides an overview of the type and amount of food that a person consumes every day which is something unique that exists in a community (Yulia, 2010, p. 23). Moehadi, et al explained consumption patterns as human reactions to their surroundings (natural or social) which had close ties to the socio-cultural community in fulfilling primary consumption and secondary consumption (Restiyani, 2010)

Thus, the consumption pattern, in general, is a tendency to fulfill needs in the context of the livelihood of a small group of people in primary needs and second needs and so on, which is the result of human reactions to their surroundings (natural or social) which have close ties to socio-culture unique to a given community (Adi, 2002)

\section{RESEARCH METHODS}

This research used a qualitative approach with a literature study method. The literature study method is a series of activities related to the methods of collecting library data, reading and taking notes, and managing research materials (Zed, 2014, p. $3)$. The data used in this research is secondary data. This secondary data were from published data, survey institutions, scientific journals and published theses both printed and online relating to people's consumption patterns. The literacy sources used in this study were selected based on four aspects, namely: 1) Evidence, 2) Objectivity, 3) Degree of Confidence, 4) Contributive Value.

\section{RESULTS AND DISCUSSION}

\section{Consumption Patterns Before the COVID-19 Pandemic}

People's consumption patterns are classified in the fulfillment of primary, secondary, and tertiary needs. The primary requirement is a requirement of survival decently. Basic needs that must be fulfilled. Primary needs include cloth, food and shelter. Secondary needs are needs that support the needs of primary needs such as 
education, health, and entertainment. While tertiary needs are needs that are created in the context of the interests of lifestyle and prestige.

The consumption pattern of the public before the COVID-19 pandemic, in general, could be described as that the poor were only able to meet their primary needs. Consumption patterns will maximize the fulfillment of primary needs, while secondary needs are not always met. The consumption pattern of the lower class for tertiary needs is not met. The community in fulfilling their needs will prioritize primary needs followed by secondary and tertiary needs.

Classification of economic levels of society by the World Bank divided into a bag a few groups where the group which group has criteria that include :

Table 2: Classification of the Economic Level of Indonesian Society according to the World Bank

\begin{tabular}{llc}
\hline No. & \multicolumn{1}{c}{ Category } & Spending Range (per month) \\
\hline 1 & Poor Group & < Rp. 354,000 \\
\hline 2 & Susceptible Group & Rp. 354,000 - Rp. 532,000 \\
\hline 3 & Towards Intermediate Group & Rp. 532,000 - IDR 1,200,000 \\
\hline 4 & Medium Safe Group & IDR 1,200,000 - IDR 6,000,000 \\
\hline 5 & High class Group & $>$ IDR 6,000,000 \\
Source: Aspiring Indonesia - Expanding the Middle Class \\
\multicolumn{2}{l}{ World Bank, 30 January 2020. (The World Bank, 2020) }
\end{tabular}

The consumption pattern that occurs in the lower/poor group and the middle class group with an expenditure level of around IDR 354,000 to IDR 1,200,000 in the pre-COVID-19 pre-pandemic period with normal work routines and normal conditions with normal income levels, there is still income turnover so that they are able to fulfill primary needs and some secondary needs While tertiary needs will be difficult to meet. Lower-level society makes it only able to meet primary needs and partly on secondary needs.

The group with an expenditure of IDR 1.2 million to IDR 6 million has economic resilience that can be considered safe so that it can meet their needs from primary to partially tertiary. The upper class also has economic resilience to meet their needs from primary to tertiary as a whole. In 2016, the results of a survey conducted by the Central Statistics Agency revealed that wages by type of work have a nominal range starting from IDR 500,000 per month up to IDR 6,000,000 per month (Indonesia Statistic Bureau, 2016). This income can become a benchmark in its influence on people's daily consumption.

In line with this, Dedi Sufriyadi stated that the poor had consumption patterns in fulfilling the primary requirement, especially fallows very little because it had been fulfilled by the harvest of paddy mainly farmers. For secondary needs, it was more focused on meeting the needs of transportation or education (Sufriyadi, 2019). Research from Refky Fielnanda and Nur Sahara suggested that there was a positive influence between the number of families and the amount of income with the consumption patterns of fishermen's households. The higher the number of incomes and the number of families, the higher the consumption pattern of the community (Fielnanda \& Sahara, 2018). In another study, it was explained that the poor had a low level of education with a non-food consumption pattern that was greater than food. The greater the number of dependents, the greater the consumption spent (Yuliana, 2014). Shania Lintang's 
research stated that there was a significant influence between income and consumption patterns, other factors such as the number of family members and wealth did not have a significant influence on consumption patterns. et al., 2019)

Based on this, when summarized in a chart, public consumption patterns before the Covid-19 pandemic would be as follows:

\begin{tabular}{|c|c|c|}
\hline & \multicolumn{3}{|c|}{ High Class Consumption Pattern } \\
\hline $\begin{array}{c}\text { Primary Needs } \\
\text { Fulfilled }\end{array}$ & $\begin{array}{c}\text { Secondary Needs } \\
\text { Fulfilled }\end{array}$ & $\begin{array}{c}\text { Tertiary Needs } \\
\text { Fulfilled }\end{array}$ \\
\hline \multicolumn{3}{|c|}{ Middle class Consumption Pattern } \\
\hline $\begin{array}{c}\text { Primary Needs } \\
\text { Fulfilled }\end{array}$ & $\begin{array}{c}\text { Secondary Needs } \\
\text { Fulfilled }\end{array}$ & $\begin{array}{c}\text { Needs Tertiary } \\
\text { Not entirely fulfilled }\end{array}$ \\
\hline \multicolumn{3}{|c|}{} \\
\hline \multicolumn{3}{|c|}{ Lower class Consumption Pattern } \\
\hline Frimary Needs & Needs Secondary & $\begin{array}{c}\text { Tertiary Needs } \\
\text { Notfilled }\end{array}$ \\
\hline
\end{tabular}

Fig 1 : Community Consumption Patterns Before the Covid-19 Pandemic

\section{Community Consumption Patterns During the Covid-19 Pandemic}

Community Consumption Patterns during the Covid-19 pandemic in meeting basic needs which are divided into several categories of needs such as primary, secondary and tertiary. Primary needs consist of the need for clothing, food, and shelter. Secondary needs are needs that support the needs of primary needs such as education, health, and entertainment. While tertiary needs are needs that are created in the context of the interests of lifestyle and prestige.

During the Covid-19 pandemic, people's consumption patterns that tend to be consumptive have become more realistic in adjusting to their needs. Human needs are met because of the availability of goods and services. Middle to low-income people, they prefer to diversify their consumption patterns (Ariningsih et al., 2020; Subdirectorate of Statistical Indicators, 2020)

Due to the small income, the allocation of food expenditure decreases. This is a characteristic of low-income people in accommodating their needs, they are more trying to diversify food ingredients with substitute ingredients or there is a tendency to consume crops and supplies that are around their homes by optimizing the surrounding land in order to maintain their food security. Regional independence is important in meeting needs and being a producer in fulfilling food consumption. This will make the surrounding environment productive (Ariani et al., 2020). Consumption of basic food items and the intensity of eating are the same as usual, but in terms of the type of food consumed, there is a decline and starting to look at substitute goods with different brands but with different types. Consumer will choose the same product at a lower price than the usual goods.

Changes in consumption patterns also occur in people with middle to upper income levels and high incomes (upper class). This change includes an increase in the allocation of more consumption on prioritizing food quality and food diversity. The consumption of food with guaranteed quality has increased significantly, such as eating instant processed in cans, as well as the consumption of spices to maintain endurance 
during this pandemic (Ariani et al., 2020; Sub-Directorate of Statistical Indicators, 2020)

Changes in spending patterns when there are large-scale social restrictions or regional restrictions make people have new consumption habits. Changes occur in the fulfillment of primary, secondary and tertiary needs. society where before the pandemic the tendency to shop directly at the market, or to buy quality food or ingredients, must be obtained directly from quality places such as supermarkets, restaurants, or so on, during this pandemic it changes the shopping style that exists in the community, in order to fulfill During the pandemic, people tend to shop at local markets or grocery stores close to where they live, or in fulfilling quality food or food ingredients online at the marketplace or using online delivery services. This has an impact on increasing online shopping on the Marketplace and online service applications. Online shopping behavior is one of the choices in fulfilling public consumption in the form of products and services during the Covid-19 pandemic. This is one of the positive solution steps in maintaining public consumption digitally during the pandemic and can improve the economic life of surrounding communities, entrepreneurs, producers and the state (Fadillaha \& Subchan, 2021)

Changes in consumption patterns during the Covid-19 pandemic did not only affect the fulfillment of needs, changes in consumption patterns during the Covid-19 pandemic also affected the field of transactions used to fulfill needs. Along with the trend of online shopping consumption on the Marketplace and online service applications. There is also a growing trend of digital transactions using digital wallets. Digital wallets can be considered as people's choice when doing outdoor activities and complying with health protocol regulations. This breakthrough transaction system also supports government programs for cashless transactions and is able to reduce face-to-face transaction activities during the Covid-19 pandemic (Aulia, 2020)

People's consumption patterns during the Covid-19 pandemic, based on the above, when described in a chart, will be as follows:

\begin{tabular}{|c|c|c|}
\hline \multicolumn{3}{|c|}{ High Class Consumption Pattern } \\
\hline $\begin{array}{c}\text { Primary Needs } \\
\text { Fulfilled }\end{array}$ & $\begin{array}{c}\text { Secondary Needs } \\
\text { Fulfilled }\end{array}$ & $\begin{array}{c}\text { Tertiary Needs } \\
\text { Not always fulfilled }\end{array}$ \\
\hline \multicolumn{3}{|c|}{} \\
\hline \multicolumn{3}{|c|}{ Middle class Consumption Pattern } \\
\hline $\begin{array}{c}\text { Primary Needs } \\
\text { Fulfilled }\end{array}$ & $\begin{array}{c}\text { Secondary Needs } \\
\text { Not entirely Fulfilled }\end{array}$ \\
\hline \\
\hline \multicolumn{3}{|c|}{} \\
\hline $\begin{array}{c}\text { Primary Need entirely fulfilled } \\
\text { Fulfilled }\end{array}$ & Lower class Consumption Pattern \\
\hline
\end{tabular}

Fig 2 : Community Consumption Patterns During the Covid-19 Pandemic

\section{E. CONCLUSION}

The consumption pattern of the public consumption pattern before the Covid-19 pandemic, in general, can be described that the lower class is only able to meet primary needs. Consumption patterns will maximize the fulfillment of primary needs, while 
secondary needs are not always met. The consumption pattern of the lower class for tertiary needs is not met. The community in fulfilling their needs will prioritize primary needs followed by secondary and tertiary needs. People with the middle class can meet almost all their needs, both primary, secondary, and tertiary needs. Furthermore, people with the upper class can meet all their needs, both primary and tertiary.

During the Covid-19 pandemic, people's consumption patterns that tend to be consumptive have become more realistic in adjusting to their needs. Human needs are met because of the availability of goods and services. This is evidenced by the lowermiddle-income to low-income people, who prefer to diversify their consumption patterns. They try to diversify their food ingredients with substitutes or there is a tendency to consume crops and supplies that are around their homes. The quantity of consumption is relatively constant but the quality is decreasing. Changes in consumption patterns also occur in people with middle to upper-income levels and high incomes (upper class). This change includes an increase in the allocation of more consumption on prioritizing food quality and food diversity. Changes in spending patterns also make people have new consumption habits. Changes occur in the fulfillment of primary, secondary, and tertiary needs. In fulfillment of food consumption, there is a change in the style of shopping in society which before a pandemic tendency to shop directly in the market or buy food or ingredient in quality must be obtained langs u ng of quality places such as supermarkets, restaurants, or others, in This pandemic period changes the shopping style that exists in the community, to fulfill during the pandemic, people are more inclined to shop at local markets or grocery stores close to where they live, or in fulfilling quality food or food ingredients online at the marketplace or using delivery services. online. In addition, the use of cashless transaction patterns when using online services also develops new trends and markets in digital wallet services and other cashless transactions.

\section{REFERENCES}

Adi, IR (2002). Thoughts on Social Welfare Development. Publishing Agency Fac. Economics University of Indonesia.

Algifari, GM (1998). Macroeconomic Theory . STIE YKPN.

Ariani, M., Setiyanto, A., \& Purwantini, TB (2020). Impact of Large-Scale Social Restrictions on the Distribution and Pattern of Household Food Consumption. In A. Suryana \& et.al (Ed.), Impact of the Covid-19 Pandemic: Adaptation Perspectives and Agricultural Socio-Economic Resilience (pp. 437 454). IAARD Press.

Ariningsih, E., Suryani, E., \& Saliem, HP (2020). Food Diversification as a Household Adaptation Strategy in Facing the Covid-19 Pandemic In A. Suryana \& et.al (Ed.), Impact of the Covid-19 Pandemic: Adaptation Perspectives and Agricultural Socio-Economic Resilience (pp. 761 - 781). IAARD Press.

Aulia, S. (2020). Digital Consumer Behavior Patterns in Utilizing Digital Wallet Applications. Journal of Communication, 12 (2), 311324. https://doi.org/10.24912/jk.v12i2.9829

Central Bureau of Statistics. (nd-a). household terms . Taken February 17, 2021, from https://www.bps.go.id/term 
Central Bureau of Statistics. (nd-b). Dependency Ratio. Statistical Reference Information System. Taken February 17, 2020, from https://sirusa.bps.go.id/sirusa/index.php/indikator/1154

Central Bureau of Statistics. (2016). Dynamic Table of Labor Wage Subjects . https://www.bps.go.id/subject/19/upah-buruh.html\#subjekViewTab5

Central Bureau of Statistics. (2020). Poverty Profile in Indonesia March $2020(56 / 07 /$ Th. XXIII; 15 July 2020, Vol. 1). Central Bureau of Statistics. https://www.bps.go.id/website/material_ind/materialBrsInd20200715120937.pdf

Dominick, S. (2007). Microeconomics (4th ed.). Erlangga.

Dusenberg, JS (1967). Income, Saving and the Theory of Consumer Behavior (1 ed.). Oxford University Press.

Fadillaha, MN, \& Subchan, M. (2021). The Impact of Covid-19 on Consumer Behavior in Using Marketplaces in Indonesia. Journal of Management Partners, 12 (1), 123-130.

Fielnanda, R., \& Sahara, N. (2018). Consumption Pattern of Fisherman's Household in Mendahara Ilir Village, Kec. Mendahara East Tanjung Jabung Regency. ILTIZAM Journal of Sharia Economic Research , 2 (2), 89-107.

Gilarso, T. (1993). Introduction to Economics: Micro Section, Volume 1 . Carnival.

Kartika, NY, \& Novitriani, S. (2021). The Impact of the COVID-19 Pandemic on Farmers' Work Patterns. PANCANAKA: Journal of Population, Family, And Human Resources , 2 (1), $36-$ 43. https://doi.org/https://doi.org/10.37269/pancanaka.v2i1.83

Indonesian Ministry of Agriculture. (2016). Decree of the Minister of Agriculture of the Republic of Indonesia Number 12/KPTS/KN.210/K/02/2016 concerning Technical Guidelines for the 2016 Movement for the Acceleration of Food Consumption Diversification . http://bkp.pertanian.go.id/storage/app/media/public information/Guidelines/PERMENTAN_P2KP_2016(1).pdF

Keynes, JM (1938). The General Theory of Employment, Interest and Money (1 ed.). Harcourt Brace.

Lintang, S., Engka, DS., \& Tolosang, KD (2019). Factors Affecting Family Consumption Patterns of State Civil Apparatus Teachers (ASN) in South Minahasa Regency (Study of SMP Negeri 1, SMA Negeri 1, SMK Negeri 1 Amurang). Scientific Journal of Efficiency, 19 (4), 48-59.

Mankiw, NG (2006). Principles of Economics Introduction to Macroeconomics . Salemba Four.

McEachern, WA (2001). Introduction to Microeconomics: A Contemporary Approach . Salemba Four.

Nopirin. (2015). Monetary Economics (4th ed.). Publishing Agency of the Faculty of Economics UGM.

Reksoprayitno, S. (2000). Macroeconomics: IS-LM Analysis And Aggregative SupplyDemand (1st ed.). Publishing Agency of the Faculty of Economics UGM.

Restiyani, T. (2010). Household Consumption Pattern of Lanting-Making Workers in Lemah Dhuwur Village, Kuwarasan District, Kebumen Regency. S1 - Thesis, Yogyakarta State University.

Singarimbun, M. (1978). Comsumption Pattern. Prism , 10 , 3-9.

Subagyo, A. (nd). Consumption, Annual and Investment . Taken January 31, 2021, from www.ahmadsubagyo.com 
Sub-directorate of Statistical Indicators. (2020). Results of the Social Demographic Survey on the Impact of Covid-19. In the Central Bureau of Statistics (07330.2006; Vol. $\quad 7, \quad$ Number 2). https://www.bps.go.id/publication/download.html?nrbvfeve=NjY5Y2IyZTg2N DY3ODdINTJkZDE3MWM0\&xzmn=aHR0cHM6Ly93d3cuYnBzLmdvLmlkL3 B1YmxpY2F0aW9uLzIwMjAvMDYvMDEvNjY5Y2IyZTg2NDY3ODdlNTJkZ DE3MWM0L2hhc2lsLXN1cnZlaS1zb3NpYWwtZGVtb2dyYWZpLWRhbXBha y1jb3ZpZC0xOS0yMDIw

Sufriyadi, D. (2019). Consumption Patterns of the Poor in Lingom Village, Indrapuri District, Aceh Besar District. Journal of Economics Science - Ubudiyah University Indonesia , 5 (1), 18-36.

Suparmoko, M. (1991). Introduction to Macroeconomics. Publishing Agency Faculty of Economics UGM.

The World Bank. (2020). Aspiring Indonesia - Expanding the Middle Class (World Bank

Report). https://openknowledge.worldbank.org/bitstream/handle/10986/33237/As piring-Indonesia-Expanding-the-Middle-Class.pdf

Wardayadi. (nd). Consumption, Saving and Investment . Taken January 31, 2021, from http://wardayadi.wordpress.com/material-ajar/class-x/konsumsi-dan-tabung-daninvestasi/

Winarno, S., \& Ismaya, S. (2007). Great Dictionary of Economics . Graphics Library.

YP, NMS (2008). Diversification of Staple Food Consumption Based on Local Potential in Realizing Food Security for Rural Households in Semin District, Gunung Kidul Regency. Journal of Development Economics , 13 (1), 51-60.

Yulia, F. (2010). Consumption Pattern, Lifestyle, Body Mass Index. Gajah Mada University Press.

Yuliana. (2014). Analysis of Consumption Patterns of Poor Families in Medan City. Journal of Economics and Finance, 2 (2), 43-55.

Zed, M. (2014). Literature Research Methods (3rd ed.). Indonesian Torch Library Foundation. 